\title{
A MULTIFACETED NUPTIAL BLESSING: THE USE OF RUTH 4:11-12 WITHIN MEDIEVAL HEBREW EPITHALAMIA
}

\author{
Avi Shmidman*
}

\begin{abstract}
When bestowing poetic blessings upon newly married couples, the medieval Hebrew poets often advance analogies to biblical figures, indicating their wish that the couple should merit the good fortune of, for instance, the forefathers Abraham, Isaac and Jacob, or of later biblical figures such as Moses, Zipporah, Phinehas, or Hannah. The most common analogy offered, however, is that of the matriarchs Rachel and Leah, as per Boaz's nuptial blessing from Ruth 4:11: "May the Lord make the woman who is coming into your house like Rachel and Leah, both of whom build up the House of Israel!" In this study, the usage of this recurring motif throughout medieval Hebrew epithalamia will be considered, so as to demonstrate its role as a focal point of poetic creativity.
\end{abstract}

The medieval Hebrew poets composed hundreds of epithalamia, celebrating nuptial occasions within the Israelite nation, while offering blessings on behalf of the newly married couples. ${ }^{1}$ Many of these blessings center upon comparisons with biblical figures. For instance,

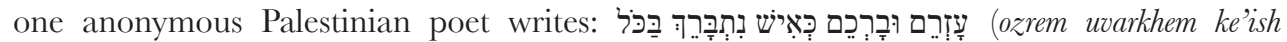
nitbarekh bakkol, "assist them and bless them as he who was blessed in all things"), ${ }^{2}$ praying that the bride and groom should merit the blessings of Abraham. Similarly, the Palestinian

\footnotetext{
* Lecturer in the Department of Literature of the Jewish People at Bar-Ilan University. Email: avi.shmidman@ biu.ac.il. I would like to thank my colleague Dr Tzvi Novick for his insightful comments on an earlier draft of this paper. Additionally, I would like to express my gratitude to the following institutions for the use of their manuscript catalogs and collections: The Ezra Fleischer Institute for the Research of Hebrew Poetry in the Genizah; the Academy of the Hebrew Language; the Institute of Microfilmed Hebrew Manuscripts of the Jewish National and University Library in Jerusalem; and the Friedberg Genizah Project. Translations of scripture within this paper follow the JPS translation of 1917. Transliterations follow the general guidelines for Hebrew and Semitic languages specified in the Encyclopaedia fudaica, 2nd ed., v. 1, 197. Where relevant, citations of poems are accompanied by their corresponding index number, as per Israel Davidson, Thesaurus of Mediaeval Hebrew Poetry, 4 vols (New York: Jewish Theological Seminary, 1924-38) (Hebrew). Finally, a note regarding my use of the term "epithalamia": etymologically, an epithalamium is a song intended specifically for the bridal chamber (based on the Greek " " the term will be used herein to refer to nuptial poems in general.

${ }^{1}$ For a chronological survey of Hebrew epithalamia through the ages, see Meir Bar-Ilan, Ateret Hatanim (Ramat Gan: self-published, 2007). For additional studies of medieval Hebrew epithalamia, see Shulamit Elizur, "Al Piyyute Hatanim ve-Haftarat Hatanim", Masekhet 1 (2002), 63-74, and Ephraim Hazan, "Shirei ha-Hatuna le-Rabi Yehuda Halevi", Dukhan 11 (1977), 27-33.

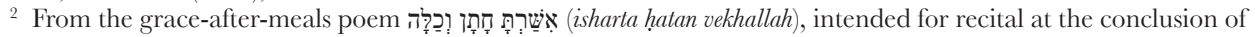
a wedding meal; see Avi Shmidman, The Poetic Versions of the Grace after Meals from the Cairo Genizah: A Critical Edition, Ph.D. Thesis (Ramat-Gan: Bar-Ilan University, 2009) (Hebrew), 658. "He who was blessed in all things" is a

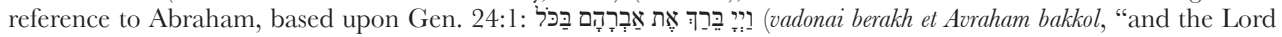
had blessed Abraham in all things").
} 


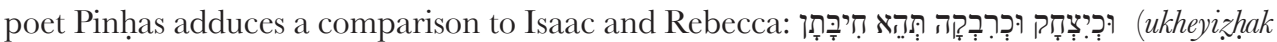
ukherivka tehe hibbatan, "and may their love be as that of Isaac and Rebecca"). ${ }^{3}$ And in a third

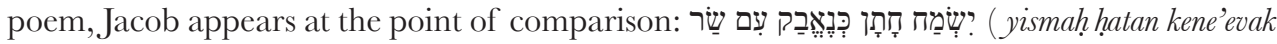
im sar, "may the groom rejoice as he who wrestled with a ministering angel". $)^{4}$ Beyond the forefathers, we find comparisons to many other additional figures, including the sons of Jacob, Moses, Zipporah, Phinehas, Hannah, Elkanah, Samuel, Mordecai, Esther, and more. However, by far the most common comparison is to the matriarchs Rachel and Leah. The use of this comparison within a nuptial setting finds its roots in the Bible itself, in the blessing offered to Boaz by the elders of the town (Ruth 4:11-12):

All the people at the gate and the elders answered, "We are witnesses. May the Lord make the woman who is coming into your house like Rachel and Leah, both of whom build up the House of Israel! Prosper in Ephrathah and perpetuate your name in Bethlehem! And may your house be like the house of Perez whom Tamar bore to Fudah - through the offspring which the Lord will give you by this young woman."

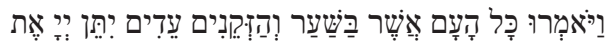

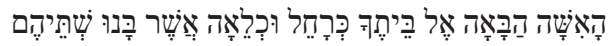

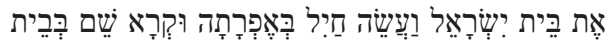

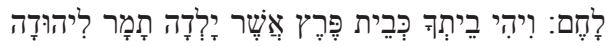

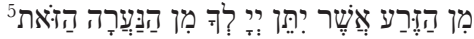

This verse effectively established a biblical paradigm for the blessing of a bride and groom, and its impact upon medieval Hebrew epithalamia was considerable. The comparison to Rachel and Leah recurs again and again throughout medieval Hebrew epithalamia from all centers of Hebrew poetic activity, including Palestine, Babylonia, Italy, Spain, and Ashkenaz.

Notably, as we shall see, the impact of the verse transcends the liturgical/paraliturgical boundary; appropriations of the verse occur within epithalamia composed for a diverse array of poetic settings. With regard to synagogue poetry, we find the verse incorporated in poetry intended for the Sabbath following a wedding (Shabbat hatan), both within strictly liturgical compositions such as qedushtaot (poems recited as part of the amidah prayer), as well as within reshut poems recited prior to calling the groom to the Torah. Outside the synagogue, the verse finds expression in many grace-after-meals poems, intended for recital at the conclusion of nuptial meals, as well as within various free-standing zemirot (songs) and pizmonim (refrain poems), devoid of any specific liturgical context.

To be sure, recurring motifs are often prone to formalization. When a motif is so common that it is simply included as a matter of course, its effect within the poetry may be severely minimized. Nevertheless, a survey of medieval Hebrew epithalamia demonstrates that the

\footnotetext{
${ }^{3}$ From the grace-after-meals poem תִּ .... (a... tithattan) for wedding meals; see Shulamit Elizur, The Liturgical Poems of Rabbi Pinhas Ha-Kohen [Hebrew] (Jerusalem: World Union of Jewish Studies, The David Moses and Amalia Rosen Foundation, 2004), 749.

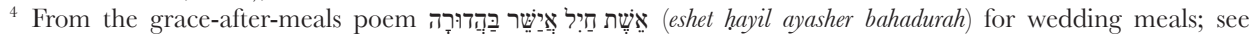
Shmidman, Grace after Meals, 692. "He who wrestled with a ministering angel" refers to Jacob, based upon Gen.

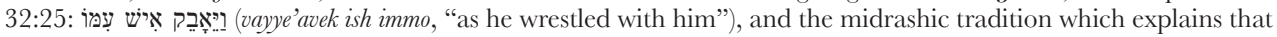
it was Esau's ministering angel who wrestled with him (Genesis Rabba 77:3).

5 Transliteration: vayyomeru kol ha'am asher basha'ar vehazzekenim edim yitten adonai et ha'ishah habba'ah el beitekha kerahel ukhele'ah asher banu sheteihem et beit yisra'el va'aseh hayil be'efratah ukera shem bevet lahem: vihi veitkha keveit perez asher yaledah tamar lihudah min hazzera asher yitten adonai lekha min hanna'arah hazzot.
} 
poets responded successfully to this challenge, creatively integrating the Rachel-and-Leah comparison in new and innovative ways, breathing new life into this old motif.

\section{$[2]$}

In many instances, in their reuse of the biblical comparison to Rachel and Leah, the medieval Hebrew poets incorporated the original blessing formulation from Ruth 4:11-12. As an initial example, I shall cite a few stanzas from an epithalamium authored by the Spanish poet Yosef ibn Abitur: ${ }^{6}$

May God make the woman who is coming into your house like Rachel and Leah

[Refrain:]

Regarding procreation and proliferation

May she be upright like the house of Perez whom Tamar bore to Fudah

May God, exalted above all Gods, give strength to the bride

As with Rachel and Leah, both of whom built up the house of Israel

[Refrain: "Regarding procreation. .."]

May He bless the work of your hand, and strengthen your goodness

May your wife be like a fruitful vine within your house

[Refrain: "Regarding procreation..."]

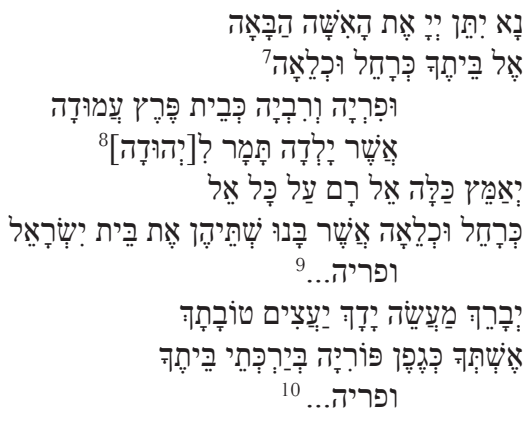

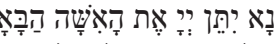

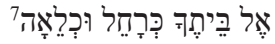

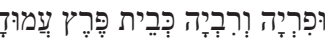

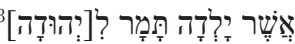

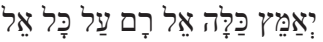

9 ופריה יקריה

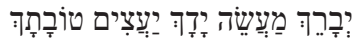

ופריה...

Prima facie, the extended verbatim citations of Ruth 4:11-12 in lines 1,2, 4 and 6 might seem lacking in originality. Nevertheless, a surprise is in store for the reader who has prior knowledge of the verses. As a result of the restructuring of the quote in the first two lines, a natural rhyme emerges within the biblical formulation: הָבָָאָה / וּכְלָאָה (habba'ah/ukhele'ah). This effect is obscured within the biblical text, because, according to the syntactic structure of the verse, enforced by the accompanying cantillation marks, it

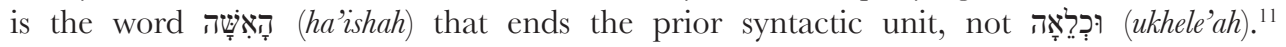

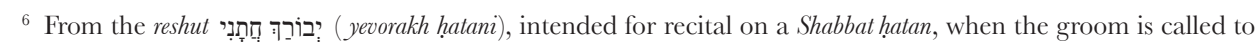
the Torah; see Ezra Fleischer, "Behinot beshirato shel rabi yosef ibn abitur", Asufot 4 (1989), 170. The text cited here differs slightly from Fleischer's text, based upon an inspection of the original manuscript (Ms. Cambridge University Library, Taylor-Schechter K25.25), and in accordance with the readings of the Historical Dictionary project of the Academy of the Hebrew Language.

7 Transliteration: na yitten adonai et ha'ishah habba'ah / el beitekha kerahel ukhele'ah.

${ }_{8}$ Transliteration (refrain): ufiryah verivyah keveit perez amudah / asher yaledah tamar lihudah.

9 Transliteration: ye'ammez kallah el ram al kol el / kerahel ukhele'ah asher banu sheteihen et beit yisra'el / ufiryah... [refrain].

${ }_{10}$ Transliteration: yevarekh ma'aseh yadakh ya'azim tovatakh / eshtekha kegefen poriyyah beyarketei beitekha / ufiryah... [refrain].

${ }_{11}$ According to medieval Hebrew rhyme norms, equivalency of a full syllable is required to form a rhyme; thus, לִ לָאָה (ishah) (le'ah) would not constitute a valid rhyme. Regarding medieval rhyme norms, see: Benjamin Hrushovski, "The Major Systems of Hebrew Rhyme from the Piyut to the Present Day (500 A.D.-1970): An Essay on Basic Concepts", Hasifrut 2 (1969), 721-49. 
Nonetheless, by use of poetic enjambment, the poet is able to repackage the verse as a poetic couplet. ${ }^{12}$

Moreover, it is worth highlighting how the extensive quotes from Ruth affect the speech situation of the poem as a whole. ${ }^{13}$ The nuptial blessing in Ruth 4:11 entails a very specific speech situation, in which a blessing is offered to the groom, about the bride. The comparison to Rachel and Leah is applied specifically to the bride, while the overarching blessing is directed, in the second person, towards the groom. And, indeed, within this poem, not only does the verse citation continue to function in this vein, but the additional material added by the poet expands upon the same speech situation. In line 5, the poet's words

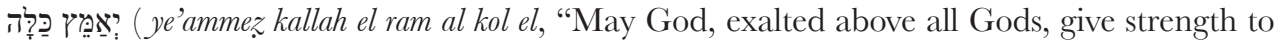
the bride") echo the blessing of "May God make the woman. .." from the verse. The poet does not address God directly, but rather, while addressing the groom, expresses his hope that God should bless the bride. Similarly, in the subsequent stanza, the poet continues to address the groom in the second person ("the work of your hand", "your goodness"), concluding the stanza with another direct biblical quote, this time from Psalms (128:3), which also matches the speech situation of Ruth $4: 11 .{ }^{14}$ Thus, the direction of the poem as a whole can be seen as an outgrowth of the original biblical scene from Ruth.

In other instances, in contrast, poets integrate the original blessing formula, yet they escape its particular speech situation by couching it within a larger framework. For instance, one unpublished epithalamium from a Cairo Genizah fragment opens with the following stanza: ${ }^{15}$

\section{Rejoice with the groom, without calamity or misfortune \\ And say, with an elevated and joyous soul: \\ May the Lord make the woman who is coming into your house like Rachel and Leah}

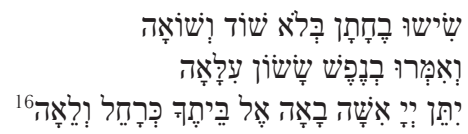

In this stanza, the poet calls upon his audience to bless the groom with Ruth's nuptial blessing. To use Austin's speech act terminology, in Ruth 4:11 the blessing comprises an illocutionary act of offering a blessing to the groom, whereas here the poet's words form a perlocutionary act, causing the audience to perform the illocutionary act of offering a

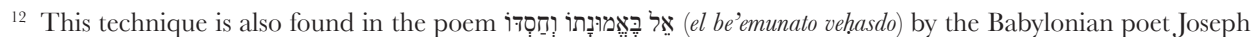

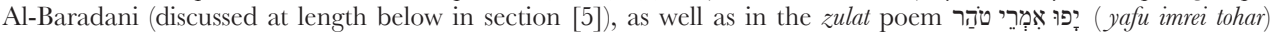
composed by the Spanish poet Isaac ibn Giyyat, and intended for recital on a shabbat hatan (see: Yonah David, The Poems of Rabbi Isaac ibn Ghiyyat [Hebrew; Jerusalem: Ah'shav Publishing House, 1987], 374). Ibn Abitur preceded ibn Giyyat, but it is possible that he learned the technique from Al-Baradani; see below, note 62 .

${ }^{13}$ Regarding the term "speech situation" and its use in the analysis of medieval Hebrew poetry, see Tzvi Novick, "Praying with the Bible: Speech Situation in the Qedushta'ot of Yannai and Bar Megas", Masoret Hapiyyut 4 (2008), 7-39.

14 This speech situation is also maintained in the two subsequent stanzas. However, it should be noted that the very first stanza of the poem is not addressed directly to the groom, but rather refers to the groom in the third person.

${ }^{15}$ This poem is structured as a pizmon (refrain-poem), and does not appear to be intended for any specific liturgical setting. It is found in Ms. Jewish Theological Seminary, Adler Collection, ENA $2953 \mathrm{fl}$.

${ }_{16}$ Transliteration: sisu vehatan belo shod vesho'ah / ve'immeru benefesh sason illa'ah / yitten adonai ishah ba'ah el beitekha kerahel vele'ah. 
blessing to the groom. ${ }^{17}$ Although the net effect is the same - that is, in either case, the end result is that the blessing is conferred upon the groom - the extra layer frees the poet from the shackles of the original speech situation, allowing him to phrase the surrounding lines from his chosen perspective, even as he quotes Ruth's blessing in full.

A similar technique is used by Yehuda Halevi, in his incorporation of the "house of Perez" analogy from Ruth 4:12:18

All, please, exalt God, and to my beloved reply:

"Groom, may your house be like the house of Perez"

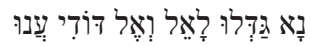

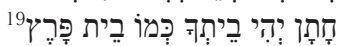

Here too, Halevi prefaces the biblical blessing with a call to his audience to pronounce it. This case is particularly striking because the poem is of the reshut lekaddish genre; that is, it was intended for recital immediately prior to the Kaddish. Normally, in a poem of this sort, the poet calls upon the congregation to rise and sanctify God's name in the upcoming prayer. Thus, by including the groom's blessing from Ruth 4:12 inside an appeal to the congregation, the poet has adapted the speech situation of the nuptial blessing to match the speech situation of the poetic genre. The end result, as Ephraim Hazan has previously highlighted, is quite astonishing: the congregation, on the verge of pronouncing praise to God, is instead instructed to direct its blessings towards the groom. ${ }^{20}$

Finally, in one anonymous Palestinian poem, we find the verse couched within a prayer to God:21

Sadness remove from their hearts

Deprive not their souls from gladness of heart

Proclaim for them happiness and joy

Delight them with the blessing of the ten people

As it is written, "All the people at the gate and the elders answered, 'We are witnesses. May the Lord make the woman who is coming into your house like Rachel and Leah, both of whom build up the House of Israel! Prosper in Ephrathah and perpetuate your name in Bethlehem!" "

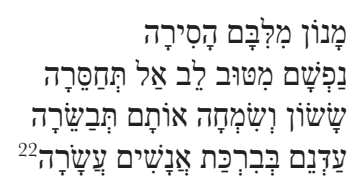

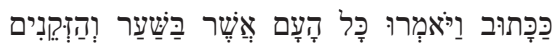

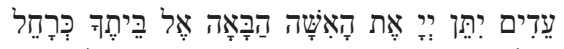

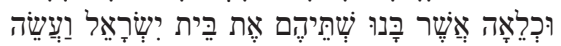

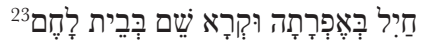

\footnotetext{
${ }^{17}$ John Langshaw Austin, How to Do Things with Words (Oxford: Oxford University Press, 1962), 98-119. Admittedly, it is possible to view the original blessing in Ruth 4:11 as a perlocutionary act supplicating God to bless the bride; if so, the poetic stanza cited here contains a perlocutionary act whose goal is to cause the audience to bless the groom with a statement that itself effects a further perlocutionary act vis-à-vis the Divine.

${ }^{18}$ From the poem intended for recital prior to kaddish on the days of Hanukkah, in the presence of a groom; see Dov Jarden, The Liturgical Poetry of Rabbi Yehuda Halevi, 4 vols (Jerusalem: self published, 1978-85) (Hebrew), IV: 984.

19 Transliteration: na gaddelu la'el ve'el dodi anu / hatan yehi veitkha kemo veit parez.

${ }^{20}$ Hazan, Shirei ha-Hatuna, 28.

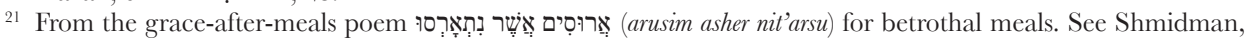
Grace after Meals, 613.

${ }^{22}$ Transliteration: manon millibbam hasirah / nafsham mittuv lev al tehasserah / sason vesimhah otam tevassera / addenem bevirkat anashim asarah.

${ }^{23}$ Transliteration: kakkatuv vayyomeru kol ha'am asher basha'ar vehazekenim edim yitten adonai et ha'ishah haba'ah el beitekha kerahel ukhele'ah asher banu shetteihem et beit yisra'el va'aseh hayil be'efratah ukera shem beveit lahem.
} 
To be sure, in this case the verse is not incorporated within the poem itself, but rather it is cited subsequently as a prooftext. ${ }^{24}$ Within the stanza Ruth's blessing is only hinted at, via the

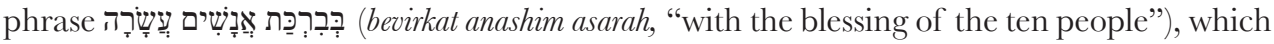

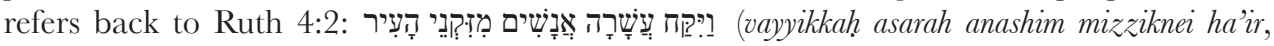
"Then [Boaz] took ten elders of the town"). Thus, instead of appropriating Ruth's blessing into the present situation, the poet references it as a prior historical event, supplicating God to bless the newly married couple with the same blessing that was conferred upon Boaz and Ruth.

\section{$[3]$}

In the previous section we examined a number of instances in which the poets cleverly alter the speech situation of the nuptial blessing from Ruth 4:11. Nevertheless, in their incorporation of the comparison to Rachel and Leah, they all maintain the basic framework of the original verse, in which the comparison is applied specifically to the bride. In other cases, in contrast, the poets abstract the model of the matriarch comparison without its overarching blessing formula, allowing them to redirect its import. For instance, in the following anonymous grace-after-meals poem, the comparison is applied to both bride and groom: $:^{25}$

He shall make them renowned and famous, and he shall shield them from all disease, and they shall rejoice together in happiness, forever, like Rachel and Leah.

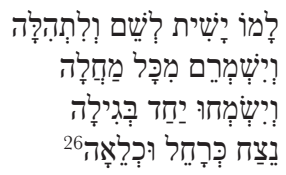

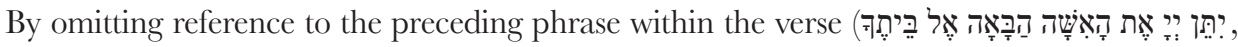
yitten adonai et ha'isha habba'ah el beitehah, "May the Lord make the woman who is coming into your house"), the poet is able to expand the range of the comparison to include both bride and groom. Nevertheless, it should be noted that the poet does not disregard the continuation

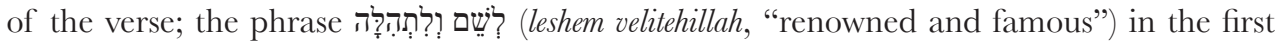
line of the stanza echoes the phrase וּקרָָא שָׁם (ukera shem, "and perpetuate your name") from the continuation of the verse. Thus, the poet maintains a clear connection to Ruth 4:11, while at the same time rephrasing the blessing in order to shift its application.

Similarly, the 7th century poet Qallir applies the analogy to the collective home of both bride and groom in the following lines: ${ }^{27}$

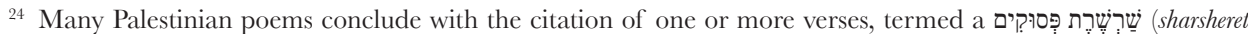
pesukim, "verse chain"); regarding this phenomenon see Shulamit Elizur, "The Chains of Verses in the Qedushta and the Ancient Benediction", Tarbiz 77 (2008), 425-73 (Hebrew).

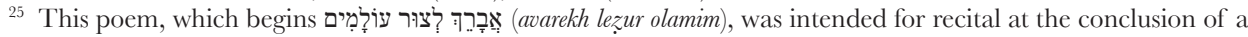
shabbat hatan meal; see Shmidman, Grace after Meals, 686.

${ }_{26}$ Transliteration: lamo yashit leshem velitehillah / veyishmerem mikkol mahalah / veyismehu yahad begilah / nezah kerahel ukhele'ah.

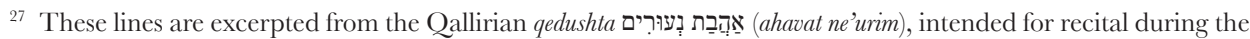
morning amidah prayer on a Shabbat hatan; see Ezra Fleischer, Hebrew Liturgical Poetry in the Middle Ages (Jerusalem: The Magnes Press, 2007²) (Hebrew), 154.
} 
As a planted stock shall they be raised Blessed with seed like Rachel and Leah

Here, too, the Rachel-and-Leah comparison is abstracted and reapplied to both bride and groom. Additionally, as in the previous example, the continuation of Ruth's blessing does still impact upon the poetry; Qallir's explicit use of the word זֶר (zera, "seed") was likely influenced by the appearance of the word in Ruth 4:12. Nevertheless, it should be noted that the term receives a significant metaphorical boost within the poem, where it is expanded to

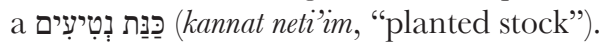

A Palestinian poet by the name of Yehudah ${ }^{29}$ employs an alternative method in order to offer blessings to both bride and groom. This poet applies the matriarchal comparison specifically to the bride, as in the original verse. However, he complements it with a corresponding blessing for the groom, comparing the groom to the patriarch Jacob. The two juxtaposed stanzas read as follows: ${ }^{30}$

The groom shall rejoice and be happy

Over the lot that he has been given

[......] shall not end

And he shall succeed with sons like the mild man ${ }^{31}$

And the bride shall be happy and rejoice

Over the portion in which she has been included

She shall raise tribes as a planted grapevine

She should be as Rachel and Leah, famous and renowned

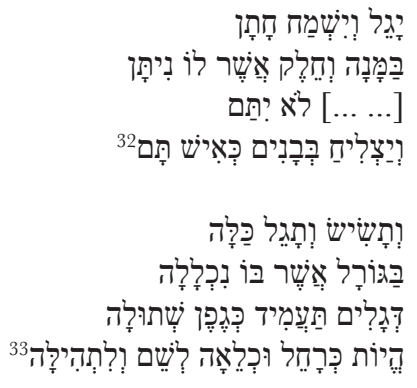

Thus, the poet retains the biblical model of Ruth's nuptial blessing, yet extends it with Rachel and Leah's corresponding patriarch, in order to present complementary blessings to bride and groom. ${ }^{34}$

A parallel shift, in the opposite direction, occurs in a poem by Yehudah Halevi. The

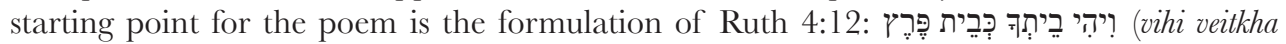
keveit perez, "and may your house be like the house of Perez"), which applies specifically to the groom. Halevi makes one slight morphological adjustment, changing בֵיתְ (veitkha, "your

28 Transliteration: kannat neti'im otam lehassi'ah / lehitbarekh bezera kerahel ukhele'ah.

29 The poem discussed herein is signed with an acrostic of "Yehudah"; however, there are a number of distinct Palestinian poets by the name of Yehudah (see: Wout Jac. van Bekkum, Hebrew Poetry from Late Antiquity (Leiden: Brill, 1998), $x v^{-} \mathrm{xvi}$ ), and the poem cannot be ascribed to any single one of them with any degree of certainty.

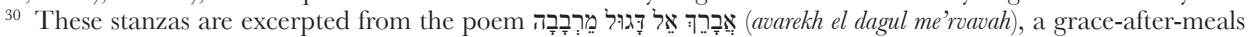
poem intended for recital at a meal celebrating the signing of the wedding contract (ketubbah). See Shmidman, Grace after Meals, 634.

31 The phrase "mild man" is an antonomasia for Jacob, based upon Gen. 25:27.

32 Transliteration: yagel veyismah hatan / bammana vehelek asher lo nittan / [......] lo yittam / veyazli'ah bevanim ke'ish tam.

33 Transliteration: vetasis vetagel kallah / baggoral asher bo nikhlalah / degalim ta'amid kegefen shetulah / heyot kerahel ukhele'ah leshem velitehillah.

${ }^{34}$ Indeed, the two blessings are parallel in content as well; in each of the stanzas, the poet uses the comparison specifically regarding the bearing and rearing of the next generation. Coupled comparisons to Rachel, Leah and Jacob are found in a number of additional poems as well, situated within a longer series of comparisons to multiple biblical figures; such cases will be examined below in section [5]. 
[singular] house") to בִָת (veitam, "their house"), thus expanding the groom's blessing to both halves of the couple: ${ }^{35}$

Their seed shall be established like the sun's light

And so should their house be like the house of Perez

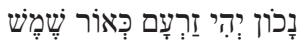

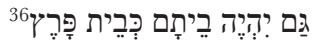

\section{$[4]$}

Other poets distance themselves even further from the biblical formulation of Ruth 4:11, expressing the ancient Rachel-Leah comparison in new terms. For instance, a Palestinian poet named Tuvia offers the following blessing to the bride: ${ }^{37}$

Pure lass, entering the canopy

Fairest of women

Of proper lineage and well-versed in modesty

May her fountain be blessed as Rachel and Zilpah

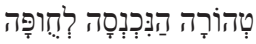

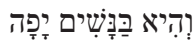

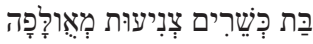

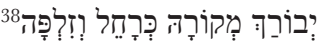

Here, surprisingly, the maid-mother Zilpah takes the place of the matriarch Leah, completing the rhyme with חופה (huppah, "wedding canopy"). To be sure, Zilpah was Leah's maid-servant (Gen. 29:24), and, on this basis, we can view Zilpah's appearance here simply as a metonymous reference to Leah herself. Nevertheless, the highly irregular metonymy serves to break the monotony of the common "Rachel and Leah" phrase. ${ }^{39}$

In another case, Qallir makes the comparison to Rachel and Leah without mentioning

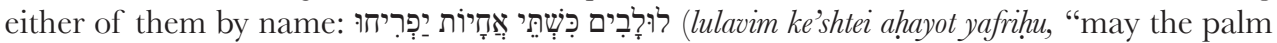
branches blossom from them, as with the two sisters").. ${ }^{40}$ Apparently, Qallir's audience was already quite familiar with the common use of the comparison to Rachel and Leah within nuptial blessings, such that the simple mention of "two sisters" sufficed. Indeed, such an audience would presumably have appreciated the novelty of the more subtle reference.

Some five hundred years later in Spain, Yehuda Halevi appeals to the same matriarchal comparison in an even more subtle fashion, in an epithalamium which opens with the following stanza: ${ }^{41}$

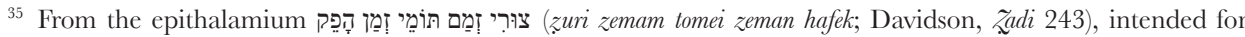
recital at a wedding canopy. See Jarden, Yehuda Halevi, IV: 993.

36 Transliteration: nakhon yehi zar'am ke'or shemesh / gam yiheyeh veitam keveit parez.

37 From a fragmentary grace-after-meals poem for a wedding meal, the extant part of which begins (rabbot banot); see Shmidman, Grace after Meals, 674.

38 Transliteration: tehorah hannikhnesah lehuppah / vehi bannashim yafah / bat kesherim zeni'ut me'ullafah / yevorakh mekorah kerahel vezilpa.

${ }^{39}$ Interestingly, in her article on Leah in the Fewish Women encyclopedia, Prof. Tikva Frymer-Kensky notes: "In Israelite tradition, the maid-mothers were forgotten, but Rachel and Leah were remembered" (Frymer-Kensky, Tikva, "Leah: Bible." Jewish Women: A Comprehensive Historical Encyclopedia, Jewish Women's Archive. http://jwa.org/ encyclopedia/article/leah-bible. Accessed October 25, 2011); in demonstrating this point, she notes the exclusive mention of Rachel and Leah within Ruth's blessing. Yet, at least in this poem, the maid-mother Zilpah does receive her due, within this very same nuptial blessing.

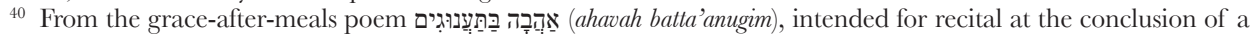
Shabbat hatan meal; see Shmidman, Grace after Meals, 683. Regarding the poem's Qallirian authorship see ibid., 59-60.

${ }^{41}$ Jarden, Yehuda Halevi, IV: 985 (Davidson, Shin 1510); this nuptial poem does not appear to have been written for a specific liturgical setting.
} 
O youth, enjoy yourself while you are young

And pluck the fruit of your happiness

You and the wife of your youth

Who is coming into your house

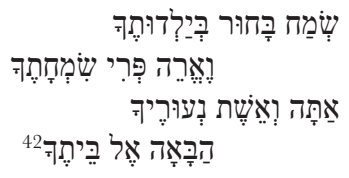

In these lines, Halevi does not explicitly advance an analogy between the bride and any

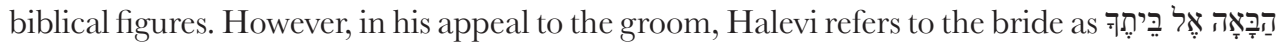
(habba'ah el beitekha, "[she] who is coming into your house") - a direct quote from Ruth 4:11. The Spanish Hebrew poets were known for their use of a technique termed (shibbuz marhiv, "broadening intertextual appropriation"), in which a quote from one part of a verse serves to bring an additional part of the verse to bear upon the poem. ${ }^{43}$ In this light,

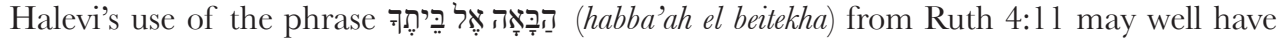
been intended to invoke the conventional Rachel-and-Leah comparison from the continuation of the verse. Thus, at the end of the day, Halevi adduces the same biblical comparison used by so many other poets before him, yet he avoids the usual explicit formulation, sufficing with only a hint for the intertextually sensitive reader.

Finally, in two poems the comparisons of Ruth 4:11-12 are shifted out of their blessing context, and used instead to refer to the present or the past. For instance, in one Ashkenazi

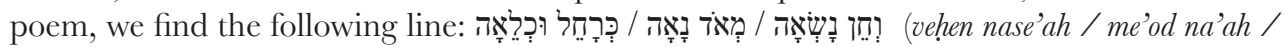
kerahel ukhele'ah, "and she has found favor, and she is exceedingly pretty, like Rachel and Leah"). ${ }^{44}$ Here, Rachel and Leah serve as models of the bride's current beauty, in contrast with their use in Ruth 4:11, where they model the bride's future flourishing family.

Similarly, in an epithalamium found in a Cairo Genizah manuscript, we find the following lines: ${ }^{45}$

And God has commanded that you should be blessed like the sons of Perez

That Tamar birthed, And may there be blessings in the land

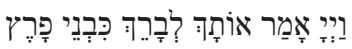

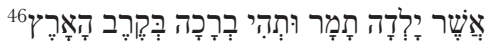

Instead of offering a blessing for the future, the poet confidently states that a Divine blessing has already been secured for the groom. In truth, the poet is most likely simply using the rhetorical technique of the "prophetic past", in which the past tense in used to convey strong confidence regarding a future outcome; in effect, then, this poem is in fact offering a blessing for the future. Nevertheless, the incorporation of the comparison from Ruth 4:12 into the prophetic past results in a remarkable departure from the original biblical formulation.

\footnotetext{
42 Transliteration: semah bahur beyaldutekha / ve'ere peri simhatekha / attah ve'eshet ne'urekha / habba'ah el beitekha.

${ }^{43}$ Regarding this poetic technique see: Shulamit Elizur, Hebrew Poetry in Spain in the Middle Ages, 3 vols (Tel Aviv: The Open University of Israel, 2004), III: 377-92.

44 Simon Hurwitz (ed.), Mahzor Vitri, 2 vols (Nuremberg: J. Bulka, 1923), II: 602.

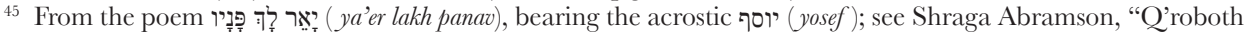
for the Bridegroom", Tarbiz 15 (1943), 62 (Hebrew). The poem does not contain any indication of a specific liturgical setting.

${ }_{46}$ Transliteration: vadonai amar otakh levarekh kivnei farez / asher yaledah tamar utehi verakha bekerev ha'arez.
} 
In the poems examined thus far, the poets have related to the bride and groom via comparisons to Rachel and Leah and to the house of Peretz, as per Ruth 4:11-12. In other poems, however, we find a far more extended series of comparisons, based upon Jewish biblical figures throughout the ages.

As an example of this phenomenon, I shall cite here, in its entirety, a previously unpublished epithalamium from a Cairo Geniza manuscript: ${ }^{47}$

May the groom be dressed with splendor like Abraham

May the bride be blessed as Sarah was blessed

The two of them are blessed

May the greatness of the groom be as the strength of Isaac

May the bride be remembered as Rebecca was remembered

The two of them are blessed

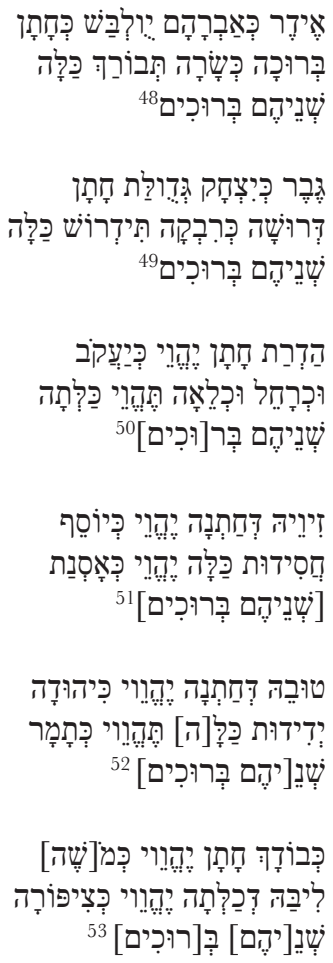

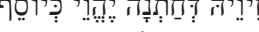

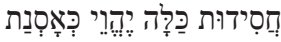

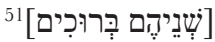

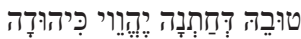

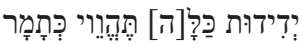

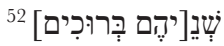

May the splendor of the groom be as that of Facob And like Rachel and Leah shall be the bride

The two of them are blessed

May the radiance of the groom be as that of Foseph

May the piety of the bride be like that of Asenath

The two of them are blessed

May the goodness of the groom be as that of Fudah

May the affection of the bride be as that of Tamar

The two of them are blessed

Your glory, groom, shall be as that of Moses

The heart of the bride shall be like that of Zipporah

The two of them are blessed

\footnotetext{
${ }^{47}$ Ms. Paris AIU IV.C 397. This nuptial poem does not provide any indication as to its author, nor does it appear to have been composed for a specific liturgical setting. I wish to thank my colleague Dr Michael Rand for his help in preparing the transcription. The poem contains a mix of Hebrew and Aramaic (for instance, the groom is

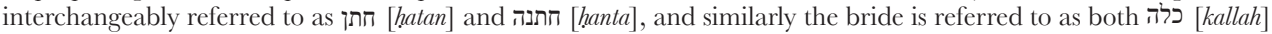
and כלתה [kaltah]). In a couple of instances the scribe appears to have erred regarding the Aramaic conjugations of

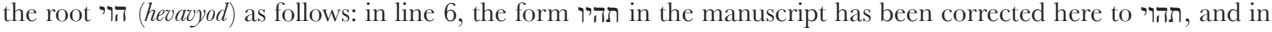
line 8, יההוי has been corrected to יהוי hasditionally, in line 7, the aberrant spelling of זיביה has been corrected to זיויה.

48 Transliteration: eder ke'avraham yulbash kehatan / berukha kesarah tevorakh kallah / sheneihem berukhim.

49 Transliteration: gever keyizhak gedullat hatan / derusha kerivkah tidrosh kallah / sheneihem berukhim.

${ }^{50}$ Transliteration: hadrat hatan yehevei keya'akov / ukherahel ukhele'ah tehevei kalletah / sheneihem berukhim.

51 Transliteration: ziveih dehatnah yehevei keyosef / hasidut kallah yehevei ke'asenat / sheneihem berukhim.

52 Transliteration: tuveih dehatnah yehevei kihudah / yedidut kallah tehevei ketamar / sheneihem berukhim.

53 Transliteration: kevodakh hatan yehevei kemoshe / libah dekhalletah yehevei kezipporah / sheneihem berukhim.
} 
This poem blesses both bride and groom by adducing comparisons to a list of six biblical couples: Abraham and Sara, Isaac and Rebecca, Jacob and Rachel/Leah, Joseph and Asenath, Judah and Tamar, and Moses and Tzipporah. At first glance, this poem might seem to have little connection with Ruth's blessing. Although the comparison to Rachel and Leah is mentioned, it is both preceded and succeeded by comparisons to other couples, and it does not stand out in any particular way. Nevertheless, the impact of Ruth 4:11-12 becomes evident upon considering the selection of Judah and Tamar in the penultimate stanza. Judah and Tamar hardly comprise an ideal couple, nor was Tamar in fact wedded to Judah; nonetheless, their appearance can be understood on the backdrop of the latter verses, which specifically mention that it was their union that produced the blessed house of Peretz. ${ }^{54}$ In this light, we may view the entire list of comparisons in this poem as an expansion of the original nuptial blessing of Ruth 4:11-12.

Similarly, in one of his epithalamia, Qallir presents a long series of comparisons, from Abraham until Esther, with Rachel and Leah sandwiched in the middle. Yet, when he does mention them, he presents the comparison in terms that clearly hark back to Ruth 4:11:

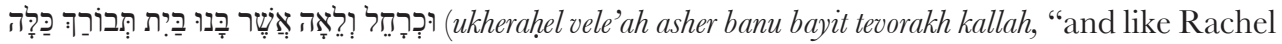
and Leah, who built up the house, shall the bride be blessed"). ${ }^{55}$ Furthermore, he continues afterward with Judah, Perez and Zerah, underscoring the connection to Ruth's blessing.

One particularly interesting example is found in a poem composed by the Babylonian poet Joseph Al-Baradani. ${ }^{56}$ Over the course of the poem, Al-Baradani adduces comparisons to a series of biblical forefathers: Adam, Noah, Abraham, Isaac, Jacob and Moses. However, despite the exclusively male focus of these comparisons, the poet also consistently integrates

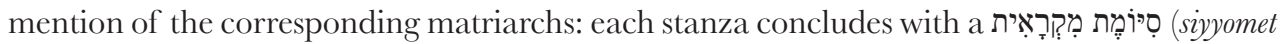
mikra'it, "scriptural clausula") which references, however indirectly, the relevant female figure. Thus, for instance, in the third stanza, we find a direct comparison to Isaac

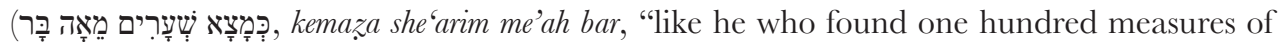
produce"), ${ }^{57}$ while the last line contains a quote from Gen. 24:50, describing the divine

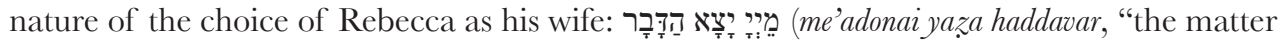
was decreed by the Lord"). Similarly, in the stanza for Moses, we first find a direct comparison

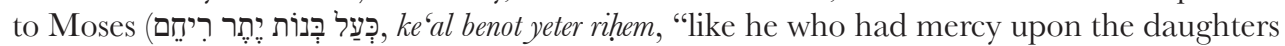

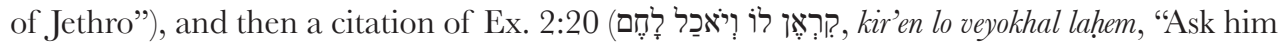
in to break bread"), in which Jethro instructs his daughters to invite Moses into the house, immediately preceding Moses' marriage to Zipporah in Ex. 2:21. Likewise, earlier in the

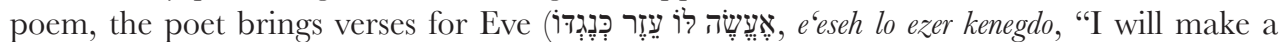

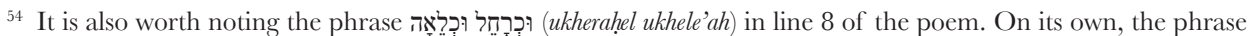
appears too generic to forge an intertextual connection. However, now that we have shown that the Ruth verses do indeed stand at the backdrop of the poem, we can also view this phrase as an echo of the words ukhele'ah) from Ruth 4:11.

${ }^{55}$ From the Qedushta poem cited earlier (note 27); see Fleischer, Hebrew Liturgical Poetry, 161.

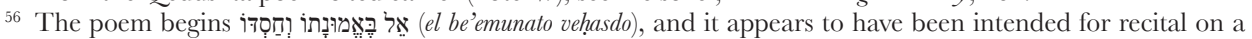
Shabbat hatan, when a groom is called up to the Torah. See Tova Beeri, The "Great Cantor" of Baghdad: The Liturgical Poems of Foseph ben Hayyim Al-Baradani (Jerusalem: The Ben-Zvi Institute, 2002) (Hebrew), 378-81. Regarding the determination of the setting for which the poem was intended (and for an analysis of the features of the poem in general), see ibid., 155.

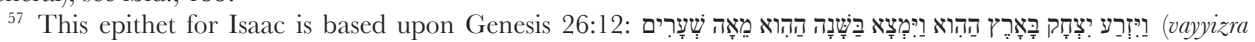
yizhak ba'arez hahi vayyimza bashana hahi me'ah she'arim, "Isaac sowed in that land and reaped a hundredfold the same year").
} 


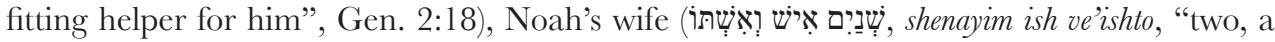

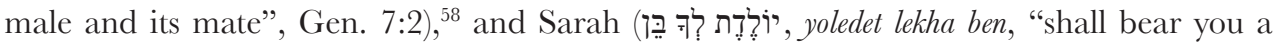
son", Gen. 17:19). On this backdrop, it is illuminating to examine the stanza regarding Jacob, Rachel and Leah:

Your ways in going,

And those in coming, shall be successful for you ${ }^{59}$

As with he who dreamt and saw a ladder

And who rolled a stone with prophetic power ${ }^{60}$

May the Lord make the woman who is coming into

Your house like Rachel and Leah

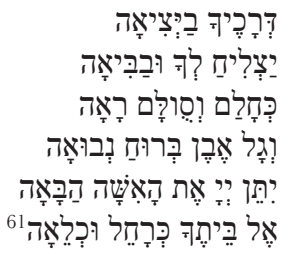

As with ibn Abitur's poem cited in section [2], here too, Al-Baradani structures the quote from Ruth 4:11 in lines 5-6 as a naturally rhyming couplet, ${ }^{62}$ and adopts the speech situation of the verse for the surrounding lines. ${ }^{63}$ However, in this case, the appearance of the Ruth verse is particularly surprising. As we have seen, in all of the other stanzas of the poem, the matriarchs are not presented as models for comparison, but rather they are simply referenced in a descriptive manner within their historical context. In contrast, in this stanza Rachel and Leah are indeed cited as exemplary models via which the bride is blessed. To a certain extent, this singular quality may be a result of the underlying structure of the poem, which

${ }^{58}$ In this case, the original verse refers generally to all of the species that entered the ark. Nevertheless, within the context of the poem, its focus narrows to Noah and his wife.

59 These two lines are ostensibly drawn from the Divine blessing to the Israelite nation in Deut. 28:6:

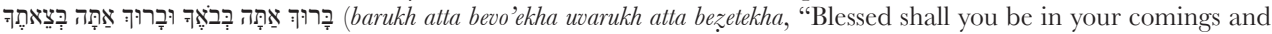
blessed shall you be in your goings"). Yet, the choice of this blessing within a nuptial poem is likely due to the potential for a double entendre (the root בוא is used in Scripture to refer to sexual relations [e.g. Gen. 38:8; Deut. 25:5], and the term ביאה [bi'ah], literally "coming", is used for such throughout Rabbinic literature [see, for instance,

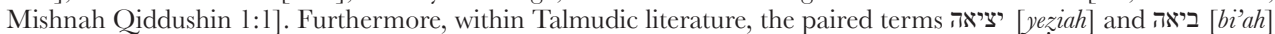
serve together in discussions of the sexual act; see, for instance, bShavuot 14b: מפני שיציאתו הנאה לו כביאתו [mi'pnei she'yezi'ato hana'ah lo kevi'ato] "because his exit is as pleasurable as his entrance"). Indeed, references to this verse do

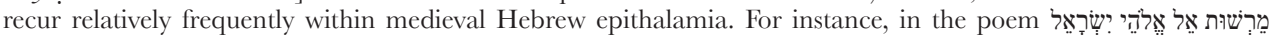

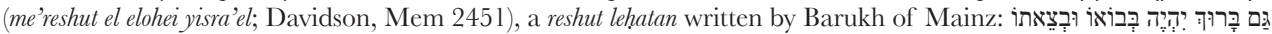
(gam barukh yiheyeh bevo'o uvezeto, "and blessed he should be in his coming and his going"; Solomon Zalman Schocken,

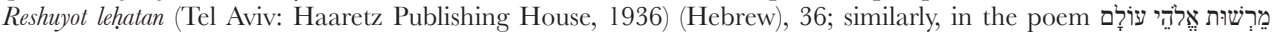

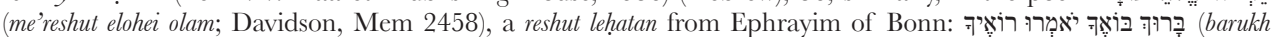
bo'ekha yomeru ro'ekha, "those who see you shall say, 'blessed be your coming",; Abraham Meir Habermann, "Liturgical Poems of Ephrayim bar Yaaqob of Bonn", Studies of the Research Institute for Hebrew Poetry in Ferusalem 7 (1958) (Hebrew), 282; and, in Spain, Yehudah Halevi incorporates the entire verse verbatim in his epithalamium

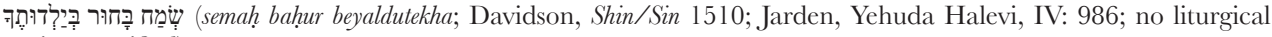
setting specified).

${ }^{60}$ These epithets for Jacob are drawn from Genesis 28-29.

${ }^{61}$ Transliteration: derakhekha vayyezi'ah / yazli'ah lekha wvabbi'ah / kehalam vesullam ra'ah / vegal even beruah nevu'ah / yitten adonai et ha'ishah habba'ah / el beitekha kerahel ukhele'ah.

${ }^{62}$ Chronologically, Al-Baradani preceded ibn Abitur by approximately one generation, and it is certainly possible that ibn Abitur learned the technique from Al-Baradani. On the other hand, it is also possible that both of these poets, living in the 10th century, at a time when enjambment was finally accepted as a valid possibility within Hebrew poetry, independently chose to format the verse in this way. Indeed, Fleischer has emphasized that throughout the preclassical and classical periods of early Hebrew poetry (through the 8th century), enjambment was virtually never used; see: Fleischer, Hebrew Liturgical Poetry, 121.

${ }^{63}$ Specifically, it is this stanza and the stanza before it that are phrased as second-person blessings directed to the groom, in accordance with the speech situation of the verse. However, the stanzas prior to these relate to the groom in the third person, and the subsequent stanza is directed to both groom and bride alike. 
mandates a direct quotation from Scripture within the concluding line. Indeed, it is only with regard to Rachel and Leah that there exists a Scriptural verse adducing their model in the offering of a blessing. Nevertheless, the use of this verse still comprises an aberration within the poem. In all of the other stanzas, the verses are drawn from Genesis, from sections dealing directly with the matriarchs and their marriage. Here too, the poet could easily have chosen one of the many verses in Genesis discussing Jacob's matrimony with Rachel and Leah. From this perspective, the choice of Ruth 4:11 within the poem reflects a deliberate departure from the overarching structure of the poem. Thus, although the comparison to Rachel and Leah might seem to occupy an unremarkable position here in the middle of a much longer list of biblical comparisons, the singular nature of this particular comparison is nevertheless highlighted within the poem.

Within the list-based epithalamia discussed so far, the role played by Ruth 4:11-12 is relatively subtle. However, in a few cases, we find the verses playing a key role in the presentation and structure of the lists. For instance, in one Qallirian poem written for a wedding meal, the author begins with the marriage of Adam and Eve, continuing with Abraham and Sarah, Isaac and Rebecca, and finally, Jacob with Rachel and Leah. The final stanza in the progression reads as follows: ${ }^{64}$

This lily, entering the canopy

Twelve may she blossom forth, with reverence

May she be blessed with fruitful produce

Build the house of the groom and bride as that of Rachel and Leah!

As it is written, "All the people at the gate and the elders answered, 'We are. May the Lord make the woman who is coming into your house like Rachel and Leah, both of whom build up the House of Israel! Prosper in Ephrathah and perpetuate your name in Bethlehem!"”

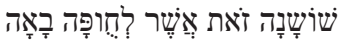

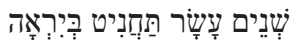

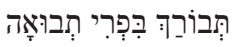

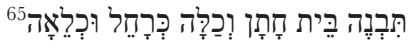

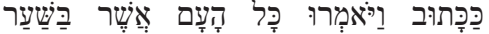

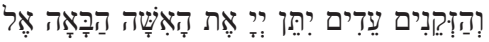

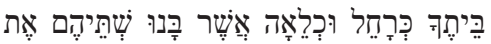

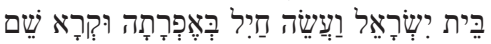

In this final stanza, the poet wishes the bride a set of children modeled after Jacob's twelve, continues with an explicit mention of the model of Rachel and Leah, and concludes with a citation of the full verse from Ruth 4:11. It would seem, however, that the verse is not simply a prooftext for the specific comparison that preceded it; rather, it is effectively positioned here as the culmination of the entire series of biblical couples, from Adam and Eve, through Rachel and Leah.

An additional example, from the reverse direction, is found in a poem from Ephrayim of Bonn: ${ }^{66}$

\footnotetext{
${ }^{64}$ From the grace-after-meals poem (ashmia bemaqhelot; Shmidman, Grace after Meals, 651. Regarding the Qallirian authorship of the poem see ibid., 59-60). Note that although this stanza concludes the portion of the poem dedicated to the aforementioned series of biblical couples, it is not the final stanza of the composition; the poem includes one additional section, in which the poet shifts his attention to the rebuilding of Jerusalem.

${ }^{65}$ Transliteration: shoshanah zot asher lehuppah va'ah / sheneim asar tahanit beyir'ah / tevorakh bi'fri tevu'ah / tivneh beit hatan vekhallah kerahel ukhele'ah.

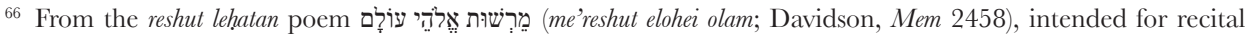
when calling a groom to the Torah on a Shabbat hatan. See Habermann, "Ephrayim of Bonn", 282.
} 
The Holy One shall make the woman coming into your house As Rachel and Leah and as Hannah

And like the two women who veiled themselves and birthed twins in their labor ${ }^{67}$

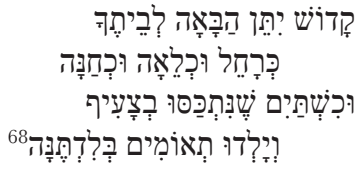

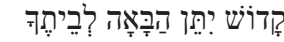

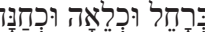

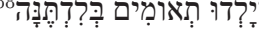

Here, the poet begins with Rachel and Leah, and then continues to bless the bride via the models of three additional biblical women: Hannah, Rebecca, and Tamar. The initial words are all drawn from Ruth 4:11, but the sentence is then expanded to include the rest of the women within the continuation of this very sentence. The verse thus stands as the basis from which all of the other comparisons emerge. ${ }^{69}$

Finally, in one Italian poem, the words וִיהִי בֵיתְף (vihi veitkha, "and may your house be") from the start of Ruth 4:12 appear as a structurally repeated phrase at the beginning of each stanza, introducing each one of the comparisons in the poem. ${ }^{70}$ The poem opens with a

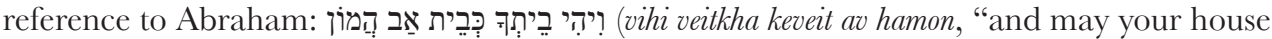
be like that of 'the father of many"”); (vihi veitkha keveit gulla bindarim, "and may your house be like that of he who was ensnared in

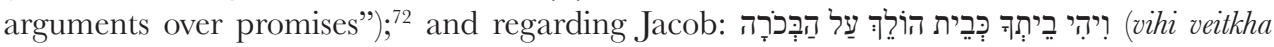
keveit holekh al habbekhorah, "and may your house be like he who walked on [the path of] the birthright"). ${ }^{73}$ In effect, the poet has imported each of the additional comparisons into Ruth's original nuptial blessing.

\section{[6]}

In all of the examples examined heretofore, Ruth's blessing was used, in one way or another, in order to relate to the newly married couple. However, in one exceptional poem, we find Ruth 4:11 quoted from a different angle altogether. This composition, a grace-after-meals poem intended for recital at a betrothal celebration, begins with a discussion of portions of

${ }^{67}$ These lines refer to Rebecca and Tamar. Rebecca covers herself with a veil in Gen. 24:65, and bears twins in Gen 25:24; Tamar veils herself in Gen. 38:14 and bears twins in Gen. 38:27.

${ }^{68}$ Transliteration: kadosh yitten habba'ah leveitekha / kerahel ukhele'ah ukhehannah / ukhishtayim shennitkassu veza'if / veyaledu te'omim belidtenna.

${ }^{69}$ The choice of Tamar and Rebecca as additional female models is, of course, not random. As noted earlier in this section, the inclusion of Tamar as a biblical model for the bride is presumably influenced by her mention in Ruth 4:12. Rebecca, in turn, is included due to her remarkable commonality with Tamar, as indicated within the poem itself. Nevertheless, what is noteworthy here is that the comparisons to these extra characters are incorporated within the original biblical blessing that was fashioned around the Rachel-Leah comparison.

${ }^{70}$ Zvi Malachi, "Shirei Zemer shel Payțane Italia ha-Qadmonim", in: The A.M. Habermann Memorial Volume (Yad leheman), ed. Zvi Malachi (Lod: Habermann Institute for Literary Research, 1983), 99. No liturgical setting is specified or indicated.

71 The epithet "the father of many" is a reference to Abraham, based on Gen. 17:4-5.

72 This epithet is somewhat cryptic. Presumably it refers to the agreement between Abraham and the Philistines over the wells, which was subsequently violated during Isaac's lifetime (Gen: 26:15); however, it is possible that the text is corrupted.

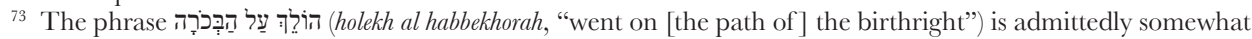

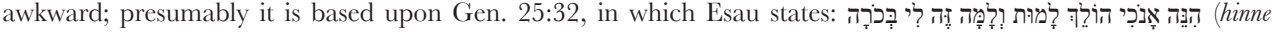
anokhi holekh lamut velamah zeh li bekhorah, "I am at the point of death, so of what use is my birthright to me?"). The poet, picking up on Esau's use of the verb הולך (holekh; literally, "walking"), applies the reverse to Jacob - if Esau is "walking" to death, away from the birthright, than Jacob is walking to the birthright. 
Jewish law pertinent to the occasion. After poetically enumerating the three primary methods of betrothal (as per Mishnah Qiddushin 1:1), the poet continues to discuss the requirement for official witnesses: ${ }^{7475}$

Long ago, He who restores the lonely [i.e., God] warned The elders of the seed of the congregation of Jews

That regarding this law [the law of betrothal], it shall be attested:

The commencement [of the betrothal] shall be performed with witnesses

As it is written, "All the people at the gate and the elders answered, 'We are witnesses. May the Lord make the woman who is coming into your house like Rachel and Leah, both of whom build up the House of Israel! Prosper in Ephrathah and perpetuate your name in Bethlehem!" ",

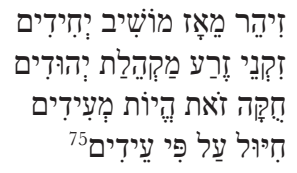

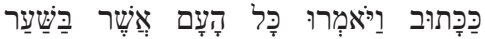

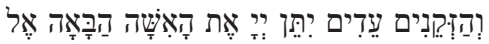

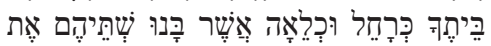

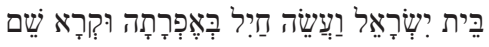

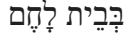

The verse is positioned here as a biblical prooftext, providing a legal precedent for the presence of witnesses at a betrothal ceremony. Indeed, the verse relates explicitly to the role of the elders as witnesses. ${ }^{76}$ Nevertheless, one can imagine the astonishment of the audience who, expecting the conventional citation of Ruth 4:11 within a blessing to the newlyweds, suddenly encounter its appearance in a purely legal setting.

\section{[7]}

In conclusion, we have traced here the usage of a single motif throughout medieval Hebrew epithalamia. In all of the cases considered, the poets made use of the same basic nuptial blessing from the book of Ruth. Yet, we have found remarkable diversity regarding the ways in which this blessing comes to the fore within the poems.

Some poets inject the blessing into a new speech situation. For instance, in a number of the poems, the blessing - originally addressed to Boaz alone - is adjusted to relate equally to both bride and groom. In other compositions, poets shift the focus more drastically, repackaging the blessing within an appeal to God, or within an appeal to the audience as a whole. To a certain extent, the choice of speech situation is guided by the liturgical setting of the poem. Thus, the reshut lehatan poems, intended from the outset as a blessing to the groom, tend to keep the focus upon the groom as in the original verse. And, conversely, in the graceafter-meals poems, which were presumably recited in the presence of both groom and bride, we generally find the blessing reapplied to both of them in an equal fashion. Nevertheless, the speech situation does not always align as expected with the liturgical position. Thus, on the one hand, Qallir blesses the bride and groom together within his qedushta poem, intended

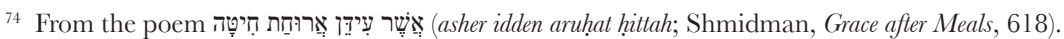

75 Transliteration: ziher me'az moshiv yehidim / ziknei zera makhelat yehudim / hukka zot heyot me 'idim / hiyyul al pi edim.

${ }^{76}$ It should be noted, however, that the Talmudic discussion regarding the requirement for witnesses (bQiddushin 65b) confines itself to Pentateuchal sources, and does not actually adduce a legal precedent from the Ruth verse.
} 
for recital within a synagogue context, ${ }^{77}$ while on the other, it is specifically within the graceafter-meals poetry, rather than within the synagogue poetry, that we find Ruth's blessing redirected to God in the second person. ${ }^{78}$

Other poets see the verse as a starting point, expanding it into a whole series of comparisons to biblical figures. Others poetically adapt the biblical phraseology to suit the new poetical setting by using enjambment to turn the verse into a poetic couplet, or by replacing an explicit reference with a literary allusion. Finally, in a few poems, the appropriation of the verse does not occur within a blessing context at all; rather, it is reworked to serve a different purpose, such as providing a description of the current state of the bride and groom, or presenting a legal precedent regarding the presence of witnesses at the ceremony. In this manner, far from turning into a banal and formalized component, the use of Ruth 4:11-12 emerges as a focal point of poetic creativity within medieval epithalamia.

\section{BIBLIOGRAPHY}

Abramson, Shraga. "Q'roboth for the Bridegroom", Tarbiz 15 (1943), 50-62 (Hebrew).

Austin, John L. How to Do Things with Words. Oxford: Oxford University Press, 1962.

Bar-Ilan, Meir. Ateret Hatanim. Ramat Gan: self-published, 2007 (Hebrew).

Beeri, Tova. The "Great Cantor" of Baghdad: The Liturgical Poems of Joseph ben Hayyim Al-Baradani. Jerusalem: The Ben-Zvi Institute, 2002 (Hebrew).

Bekkum, Wout Jac. van. Hebrew Poetry from Late Antiquity. Leiden: Brill, 1998 (Hebrew).

David, Yonah. The Poems of Rabbi Isaac ibn Ghiyyat. Jerusalem: Ah'shav Publishing House, 1987 (Hebrew).

Davidson, Israel. Thesaurus of Mediaeval Hebrew Poetry, 4 vols. New York: Jewish Theological Seminary of America, 1924-38 (Hebrew).

Elizur, Shulamit. "Al Piyyute Ḥatanim ve-Haftarat Ḥatanim”, Masekhet 1 (2002), 63-74 (Hebrew).

_. The Liturgical Poems of Rabbi Pinhas Ha-Kohen. Jerusalem: World Union of Jewish Studies, The David Moses and Amalia Rosen Foundation, 2004 (Hebrew).

— Hebrew Poetry in Spain in the Middle Ages, 3 vols. Tel Aviv: The Open University of Israel, 2004 (Hebrew).

_ _ "The Chains of Verses in the Qedushta and the Ancient Benediction", Tarbiz 77 (2008), 425-73 (Hebrew).

Fleischer, Ezra. "Behinot beshirato shel rabi yosef ibn abitur", Asufot 4 (1989), 127-88 (Hebrew).

— Hebrew Liturgical Poetry in the Middle Ages. Jerusalem: The Magnes Press, $2007^{2}$ (Hebrew).

Frymer-Kensky, Tikva. "Leah: Bible", in: Jewiish Women: A Comprehensive Historical Encyclopedia, Jewish Women's Archive. http://jwa.org/encyclopedia/article/leah-bible. Accessed October 25, 2011.

Habermann, Abraham Meir. "Liturgical Poems of Ephrayim bar Yaaqob of Bonn", Studies of the Research Institute for Hebrew Poetry in Ferusalem 7 (1958), 215-96 (Hebrew).

Hazan, Ephraim. "Shirei ha-Hatuna le-Rabi Yehuda Halevi", Dukhan 11 (1977), 27-33 (Hebrew).

Hrushovski, Benjamin. "The Major Systems of Hebrew Rhyme from the Piyut to the Present Day (500 A.D.-1970): An Essay on Basic Concepts", Hasifrut 2 (1969), 721-49 (Hebrew).

Hurwitz, Simon (ed.). Mahzor Vitri, 2 vols. Nuremberg: J. Bulka, 1923.

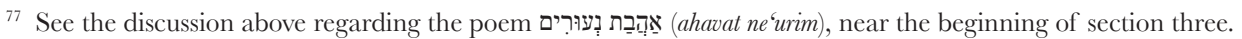

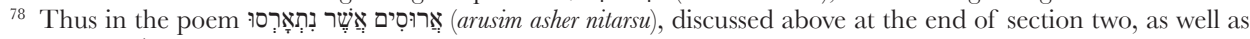

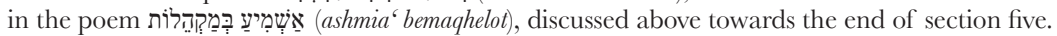


Jarden, Dov. The Liturgical Poetry of Rabbi Yehuda Halevi, 4 vols. Jerusalem: self-published, 1978-85 (Hebrew).

Malachi, Zvi, "Shirei Zemer shel payțane Italia ha-Qadmonim", in: The A.M. Habermann Memorial Volume (Yad leheman), ed. Zvi Malachi. Lod: Habermann Institute for Literary Research, 1983, 73102 (Hebrew).

Novick, Tzvi. "Praying with the Bible: Speech Situation in the Qedushta'ot of Yannai and Bar Megas", Masoret Hapiyyut 4 (2008), 73-9 (Hebrew).

Schocken, Solomon Zalman. Reshuyot lehatan. Tel-Aviv: Haaretz Publishing House, 1936 (Hebrew).

Shmidman, Avi. The Poetic Versions of the Grace after Meals from the Cairo Genizah: A Critical Edition, Ph.D. Thesis. Ramat-Gan: Bar-Ilan University, 2009 (Hebrew). 